\title{
Edremit Körfezi'nde Tarımsal Arazi Kullanımı Uygunluk Düzeylerinin Değerlendirilmesi
}

\section{Assessment of Agricultural Land-Use Suitability Levels in the Gulf of Edremit}

\author{
Çağan ALEVKAYALI ${ }^{1}$ (D), Şermin TAĞIL ${ }^{2}$ (D) \\ ${ }^{1}$ Süleyman Demirel Üniversitesi, Fen Edebiyat Fakültesi, Coğrafya Bölümü, Isparta, Türkiye \\ ${ }^{2}$ İzmir Bakırçay Üniversitesi, Fen Edebiyat Fakültesi, Coğrafya Bölümü, İzmir, Türkiye
}

ORCID: Ç.A. 0000-0001-7044-8183; Ş.T. 0000-0001-9496-6823

\section{öz}

Tarımsal üretim, insanların besin ihtiyaçlarını karşılamaya yönelik geçmişten bu yana süre gelen faaliyetleri ifade etmektedir. Tarımsal üretim süreci birçok aşamada arazi ile etkileşime girmektedir. Arazi ve tarım arasındaki ilişki özellikle üretim açısından ön plana çıkmaktadır. Böylece tarımsal üretimin devamlılığı arazinin uygun biçimde kullanılmasıyla yakından ilişkilidir. Kısaca tarımda sürdürülebilirliğin sağlanması doğru arazi kullanımına bağlıdır. Bu çalışmanın amacı Edremit Körfezi ve çevresinde ekili arazilerin tarımsal faaliyetlere uygunluk düzeylerinin çeşitli kriterler açısından belirlemesi ve elde edilen sonuçların mevcut arazi kullanımları ile karşılaştırılmasıdır. Tarıma uygun alanların belirlenmesi için Coğrafi Bilgi Sistemleri tabanlı Çok Kriterli Karar Verme (ÇKKV) analizlerinden Analitik Hiyerarşi Süreci'nden (AHS) yararlanılmıştır. Elde edilen bulgular çalışma alanı sınırlarında tarıma çok uygun olduğu belirlenen bölgede yani verimli tarım arazileri üzerinde birçok yerleşmenin kurulduğunu göstermektedir. Ayrıca orman alanı ile tarıma elverişli olduğu tespit edilen alan arasında, bozuk koru ve ekili alanlardan oluşan bir geçiş bölgesi olduğu tespit edilmiştir. Çevresel parametreler arazi uygunluk seviyelerinin belirlenmesi konusunda dikkate alındığında çalışma alanı içerisinde ekili tarım alanlarının üst sınırlarına ulaştığı görülmektedir. Böylece gün geçtikçe artan gıda ihtiyacının karşılanması kaçınılmaz olduğu göz önünde bulundurulduğu takdirde orman arazilerinin tarım arazilerine dönüşme riski ile karşı karşıya olduğu anlaşılmaktadır. Edremit Körfezi'ndeki tarım alanlarının potansiyeline uygun olarak kullanılması tarımsal verimliliğin artmasında olumlu etkiler yaratmaktadır. Ayrıca tarım arazilerden uygunluk düzeyleri kapsamında yararlanılması birçok ekosisteme ev sahipliği yapan orman örtüsünün zarar görmesinin önüne geçilmesi konusunda kilit bir rol oynamaktadır.

Anahtar kelimeler: Tarıma Uygun Alanlar, Çevresel Duyarlılık, Analitik Hiyerarşi Süreci

\section{ABSTRACT}

The concept of agricultural production refers to the activities that people carry out to meet their nutritional needs. Such activities have been carried out since ancient times to meet the nutritional needs of people. The process of agricultural production interacts with the land at many stages. The relationship between land and agriculture is particularly visible in regards to production. Thus, the continuity of agricultural production depends on the proper use of the land. In short, ensuring sustainability in agriculture depends on proper land use. The aim of this study is to determine the suitability of cultivated lands for agricultural purposes and to compare the obtained results with current land use in the Gulf of Edremit and its surroundings using various criteria. The Analytical Hierarchy Process (AHS), based on Geographic Information Systems-based Multi-Criteria Decision Making (MCDM) analysis, was used to identify areas suitable for agriculture. According to the findings many settlements were established in fertile regions which were determined to be very suitable for agriculture. In addition, a transition zone consists of unproductive forest land was established between the forest area and agricultural land. The findings of our study showed that cultivated agricultural areas in our study area reached their upper limits when the environmental parameters were taken into consideration in determining the level of suitability of the land. Thus, it is understood that the forest cover faces the threat of new agricultural areas being opened in line with the increasing food need. The use of agricultural areas in accordance with their potential allowed for an increase in agricultural productivity within the study area. In addition, the careful utilization of agricultural lands within the scope of eligibility levels plays a key role in preventing the damage of the forest cover which hosts many ecosystems.

Keywords: Agricultural Land Suitability, Evironmental Sensitivity, Analitic Hiyerarchy, Process

Başvuru/Submitted: 28.08.2019 • Revizyon Talebi/Revision Requested: 10.12.2019 • Son Revizyon/Last Revision Received: 26.02 .2019 • Kabul/Accepted: 05.05.2020 - Online Yayın/Published Online: 04.06.2020

Sorumlu yazar/Corresponding author: Şermin TAĞIL / sermin.tagil@bakircay.edu.tr

Atıf/Citation: Alevkayali, C., Tagil, S. (2020). Assessment of agricultural land-use suitability levels in the gulf of Edremit.. Cografya Dergisi. Advance online publication. https://doi.org/10.26650/JGEOG2019-0028 


\section{EXTENDED ABSTRACT}

The use of suitable land for agricultural activities is very important for sustainable agricultural development. Therefore, there is a strong relationship between land, agriculture and production. Poor health in any one of the areas of agriculture, food production, and land use will invariably cause adverse effects in the other areas. Thus, incorrect and unplanned use of land causes undesirable consequences such as damage or depletion of natural resources with an increase in soil erosion and a decrease in land productivity. Considering the limitation of natural resources, it is understood that these limited resources are closely related to land use and also land use planning.

Land use planning for sustainable land management should be based on economy and ecology and on the balance between these two variables. In this equation, ecology refers to environmental protection, while economy means human activities, and justice specifies the balance between them. In terms of sustainability, conflicts between these components are effective in giving the final shape to land use and land cover changes.

Changes in the land need to be handled within the scope of many criteria because land use consists of complex systems with social and ecological dimensions. Studies to determine the potential of land for agricultural purposes are generally based on suitability analyzes that are performed within the scope of Geographical Information Systems (GIS) platform.

Environmental components are the most important criteria for successful decision-making and planning studies related to the regulation of the land-use situation using methods based on spatial technologies. Spatial planning studies to prevent any environmental problems that may arise as a result of changes in the use of land are carried out within the scope of arranging suitable plans in the areas of agriculture, forest, settlement, pasture and transportation. The aim of this study was to determine suitable areas for agriculture within the scope of interactions between agriculture and environment within spatial interactions in the study area which was limited to Edremit Bay and its vicinity.

The boundaries of the selected study area are the part of the Gulf of Edremi in the north of the Aegean Region, which continues from Altınoluk in the north to Burhaniye in the south and which passes through the water section line. The most important reason for limiting the study area is the high density of structuring and tourism activities şn that region.

In this study, soil depth, soil stoniness, slope, land use, distance to water resources and Environmental Sensitivity Area Index (ESAI) were classified into the appropriate categories for the determination of suitable areas for agriculture. The suitability classes were defined follows: most suitable, moderately suitable, marginally suitable, currently not suitable and permanently not suitable. Thus, the Analytical Hierarchy Process was used to weigh the criteria for which classes of suitability were formed. The relations were weighted in order to form alternative evaluations for the purpose of establishing the decision-making process and were obtained by referring to 24 expert opinions.

Initial observations show that the areas which are suitable for agriculture correspond to the plain floor which is generally known to consist of alluvial deposits. Of noteworthy mention is that the distribution of areas most suitable for agriculture are squeezed into a narrow area behind the northern coasts, but partially expanded in the plains towards the inner parts of the southern shores. This region, which is determined as the most suitable area for agriculture, corresponds to areas where agricultural activities are also intense. In addition, important settlements in this region such as Edremit, Burhaniye, Akcay, and Altinoluk are located above these agricultural areas. Accordingly, it is understood that if the settlements between the cultivated areas and the olive groves were expanded to include the surrounding area, the agricultural areas would first be damaged. Another problem with the suitable areas is that the olive groves are in contact with forest areas. This could cause the risk of forest land opening up for agriculture.

The observations in the field show that the areas which are not suitable for agriculture have two different structures. The first is rocky terrains or valleys with high slopes where there is insufficient soil development for agriculture. The other is environmentally important forests and regions with natural ecosystems. Moreover, the use of environmental values in the model constitutes the reasons for which the ecologically important Mount Ida and Madra Mountain are not suitable for agriculture. 
The results of the model coincide with current land use, so we can conclude that the findings of this research are suitable for consideration in the decision-making process regarding land-use. According to the results of the study, the agricultural areas in the Gulf of Edremit are facing the pressure of settlement and the threat of land degradation. In previous studies, the land cover change occurred as some parts of agricultural areas transformed into settlement areas and forests had become agricultural areas. Moreover, forest areas are the only areas where agricultural activities can expand in line with decreasing agricultural areas and increasing food needs. 


\section{GÍRIŞ}

Tarım, yeryüzündeki en önemli ekonomik faaliyetlerden biri olmasının yanında yaşamın kaynağı olarak görülen toprak ile yakından ilişkilidir (Tümertekin ve Özgüç, 2015). Dahası tarım bitkisel üretim, hayvansal üretim, su ürünleri üretimi, silvikültürel üretim ve ormancılık faaliyetleri gibi geniş bir üretim ve tüketim süreci olarak tanımlamaktadır (Doğanay, 2011). Tarımsal faaliyetlerin arazi ile olan etkileşimi üretim kısmında toprak ile başlamakta ve tüketim aşamasına kadar devam etmektedir. Böylece tarım ve arazi arasındaki ilişkisi sadece üretim açısından değil tüketim sürecini de kapsayan uzun bir süreçte devam etmektedir.

Tarımsal faaliyetler, arazi kullanımı açsından değerlendirildiğinde arazi örtüsünün değişim sürecinde etkili olan unsurlardan biridir. Böylece ekili-dikili tarımsal üretim faaliyetleri ve arazi kullanımı süreçleri arasında yakın ilişkiler bulunmaktadır. Örneğin; tarımsal faaliyetlerin uygun üretim koşularında yürütülmemesi verim açısından problemler yaratmaktadır.

Arazi kullanımının yanlış ve plansız bir biçimde yönetilmesi tarımsal faaliyetlerin olumsuz etkilenmesi yanında duyarlı ekosistemlerin bozulması, toprak erozyonunun artması ve çeşitli canlıların habitatının zarar görmesi gibi istenmeyen sonuçlara neden olmaktadır (Yılmaz, 2005). Doğal kaynakların sınırlılığ dikkate alındığında birçok canlıya ev sahipliği yapan arazilerin gelecek nesillere aktarılabilmesi bunların sürdürülebilir kullanımıyla yakından ilişkilidir. Böylece tarımsa sürdürülebilirliğin sağlanması için atılacak adımların başında arazi kullanımı konusundaki kararların titizlikle ele alınması gerekmektedir. Bu süreç kapsamında alınması gereken ilk karar arazi kullanımı ve çevre arasında dengenin kurulmasıdır (Kurucu ve Günerhan, 2013). Bu dengenin kurulması konusundaki uygulamalardan en bilineni Arazi Kullanım Planlamaları'dır (Alevkayalı, 2018). Arazi Kullanım Planlamaları, 5403 Nolu Toprak Koruma ve Arazi Kullanım Kanununda tanımlanmıştır. Bu tanımlamaya göre "Her ölçekte plânlamaya temel oluşturmak üzere, toprağın ve diğer çevresel kaynakların bozulmasın önlemek için ekolojik, toplumsal ve ekonomik şartlar gözetilerek sürdürülebilirlik ilkesine uygun, farklı arazi kullanım şekillerini oluşturmaya yönelik toprak ve su potansiyelinin belirlenip, sistematik olarak değerlendirilmesini ve birbirleri ile olan ilişkilerini ortaya koyan rasyonel planlardır" (Toprak Koruma ve Arazi Kullanımı Kanunu, 2005).

Sürdürülebilir arazi yönetimi kapsamında tasarlanan Arazi Kullanım Planları ekonomi ve ekoloji arasındaki dengenin kurulması temeline dayandırılmaktadır (Berke vd., 2006). Sağlıklı arazilerin gelecek nesillere aktarılması adına yapılan düzenlemelerin başarısı arazi uygunluk düzeylerinin belirlendiği kriterlerin güvenilirliğine bağlıdır (Akıncı, Özalp ve Turgut, 2013). Kısaca tarım arazilerinin uygunluk düzeylerine göre ele alınan kriterler ekonomi, ekoloji ve toplumun beklentilerinin gözetilerek oluşturulmalıdır (Alevkayalı, 2018). Bunun yanında ekonominin itici güçlerinden biri olan tarımsal faaliyetlerin toprak ve diğer çevresel parametrelerden ayrı düşünülmemelidir.

Arazi kullanımının ekonomik, sosyal ve ekolojik boyutları olan kompleks sistemlerin etkileşiminden meydana gelmesi; arazi örtüsünde meydana gelen değişimlerin birçok açısından ele alınmasını zorunlu kılmaktadır. Arazilerin kullanımına yönelik potansiyellerinin belirlenmesine kapsamındaki çalışmalar dikkate alındığında Coğrafi Bilgi Sistemleri (CBS) platformunda gerçekleştirilen uygunluk analizlerinin sıklıkla tercih edildiği görülmektedir (Akıncı vd., 2013; Çavuş ve Koç, 2015; Dağlı ve Çağlıyan, 2016; Demir vd., 2011; Malczewski, 2004).

Arazi kullanımı uygunluk analizleri diğer mekânsal analizlerde olduğu gibi çok sayıda çelişkili, orantısız ve alternatif dizilime sahip kriterlerin bütüncül bir biçimde değerlendirilmesiyle gerçekleştirildiğinden Coğrafi Bilgi Sistemleri tabanlı Çok Kriterli Karar Verme (CBS-ÇKKV) analizlerinin kullanımına oldukça uygundur (Malczewski, 2006). Bundan dolayı arazi uygunluk çalışmalarında CBSÇKKV analizleri kapsamındaki Ağırlıklı Doğrusal Kombinasyon (ADK), Sıralı Ağırlıklı Ortalama (SAO), Analitik Hiyerarşi Süreci (AHS), İdeal Nokta Yöntemi (IDA), Bulanık Mantık, ELECTRE, PROMETEE ve Yapay Sinir Ağları gibi yöntemler kullanılmaktadır (Çavuş ve Koç, 2015; Malczewski, 2004). Sayıları oldukça fazla olan ÇKKV analizleri arasında AHS, sınıflandırılmış nitel veriler ile nicel verilerin bir arada kullanılmasına, kriterler arasında karşılaştırmalar yapılmasına ve çoklu alternatiflerin oluşturulmasına olanak tanımaktadır (Çavuş ve Koç, 2015). Özellikle karar vericilerin sorunlar karşısında birbirinden farklı alternatiflerle net çözümler sunamadığı durumlarda AHS oldukça etkili bir yöntem olduğu bilinmektedir (Özdağoğlu ve Özdağoğlu, 2007).

\section{AMAÇ VE YÖNTEM}

\subsection{AMAÇ}

Arazi kullanımının düzenlenmesine yönelik karar-verme ve planlama çalışmalarının başarıya ulaşması çevreye ait bileşenlerin çok boyutlu değerlendirilmesine bağlıdır (Bouhata ve Kalla, 
2014). Arazilerin kullanımındaki değişimler sonucunda ortaya çıkan veya çıkabilecek çevresel sorununun önüne geçilmesi konusunda yapılan mekânsal planlama çalışmaları genellikle tarım, orman, yerleşme, mera ve ulaşım konularında uygun alan planlamalarını düzenlenmesi şeklinde gerçekleştirilmektedir (Yılmaz, 2005). Bu çalışmalar arasında Tarıma Uygun Alanların Belirlenmesine (TUAB) dayandırılan çalışmalar Birleşmiş Milletlerin Sürdürülebilir Gelişim Hedeflerinden biri olan küresel gıda güvenliğinin sağlanması konusunda en çok tercih edilen uygulamalardan biridir (Akpoti vd., 2019). Edremit Körfezi, Kazdağları ve Madra Dağı arasında yer alan zeytin tarımının yoğun bir biçimde yürütüldüğü bir bölgedir. Son yıllarda Edremit Körfezi'nde zeytinliklerden oluşan alanların özellikle yerleşmelere yakın alanların önemli bir kısmı ikincil konutların artması sonucunda tahrip edilmiştir (Kocadağl1, 2009). Bu çalışmada Edremit Körfezi’nde tarım alanları üzerindeki baskıyı tespit etmek ve ekili-dikili tarımsal faaliyetlerinin uygun arazi koşullarında gerçekleştirilip gerçekleşmediğini belirlemek amacıyla tarıma uygun alanların tespit edilmesi kapsamında bir arazi kullanım planlaması tasarlanmıştır. Tarımsal uygunluğun belirlenmesi konusunda Tarım ve Orman Bakanlığ 1 tarafindan yürütülen uygulamalarda Arazi Kullanım Kabiliyet Sınıflaması ya da Arazi Yetenek Sınıflandırması şeklinde tanımlanan bir ölçek kullanılmaktadır. Arazi Yetenek Sınıflandırması toprağı korumak amacıyla 1. sinıf olarak adlandırılan en iyi ve en ekonomik şekilde tarım yapılabilen araziler ile 8. sınıf olarak adlandırılan hiçbir tarıma elverişli olmayan, çayır veya ormanlık olarak dahi kullanılamayan arazilerin yeteneğine göre 1 ile 8 sinıf arasında tarımsal verimliliğin kademeli olarak azaldığ 1 bir sınıflandırma yaklaşımıdır (Tarım ve Köy İşleri Bakanlığı, 2008). $\mathrm{Bu}$ çalışmada tasarlanan modelin farkı arazilerin tarıma uygunluğunun tarım-çevre etkileşimi kapsamında değerlendirilmesidir. Böylece bu çalışmada tasarlanan modelin özgünlüğü toprak başta olmak üzere birçok çevre bileşenlerinin dikkate alındığı Kosmas (1999) tarafından ilk olarak ortaya konulan Çevresel Duyarlılık Alan İndeksi'nden (ÇDAİ) yararlanılmasıdır. ÇDAİ, MEDALUS (Mediterranean Desertification and Land Use) Akdeniz Havzası'nda çölleşme ile mücadele kapsamında kullanılan projenin uygulama kısmında yararlanılan modeli ifade etmektedir.

\section{2. Çalışma Alanı}

Çalışma alanın sınırları Edremit Ovasını kapsayacak şekilde bazı akarsuların Havran Çayı, Zeytinli Çayı, Karınca Deresi ve Ilıca Deresi başta olmak üzere Altınoluk-Gömeç ilçeleri arasında yer alan akarsuların su bölümü sınırlarından geçirilmiştir (Şekil 1). Çalışma alanında su bölümü çizgisinin sınırlarının temel alınmasının nedeni çevre sorunları ve doğal kaynakların planlanmasına yönelik çalışmaların hidrografik havza yaklaşımına dayandırılmalarıdır (Garipağaoğlu, 2012). Çalışma sahasının kapladığı alan yaklaşık $1580 \quad \mathrm{~km}^{2}$ 'dir. Çalışma sahası sınırları içerisinde Kazdağ Milli Parkı ve Edremit, Havran, Burhaniye gibi Balıkesir'in önemli yerleşmeler yer almaktadır. Edremit Körfezi, Babakale Burnu'ndan başlayarak Ayvalık'a kadar devam daha geniş bir alanı ifade etmektedir. Çalışma alanının sınırlarının belirlenmesinde arazi çalışmaları kapsamında Gömeç ve Altınoluk arasındaki bölgede konumlanan yerleşmelerin çevresinde son yıllarda yapılaşma ve turizm faaliyetlerinin yoğunlaşmasıdır (Tăğl, 2014). Çalışma alanının belirlenmesinde dikkate alınan diğer bir etken Edremit Ovası'nın ülke zeytin üretiminde önemli bir üretim miktarı ve potansiyeline sahip olmasıdır (Kocadağlı, 2009).

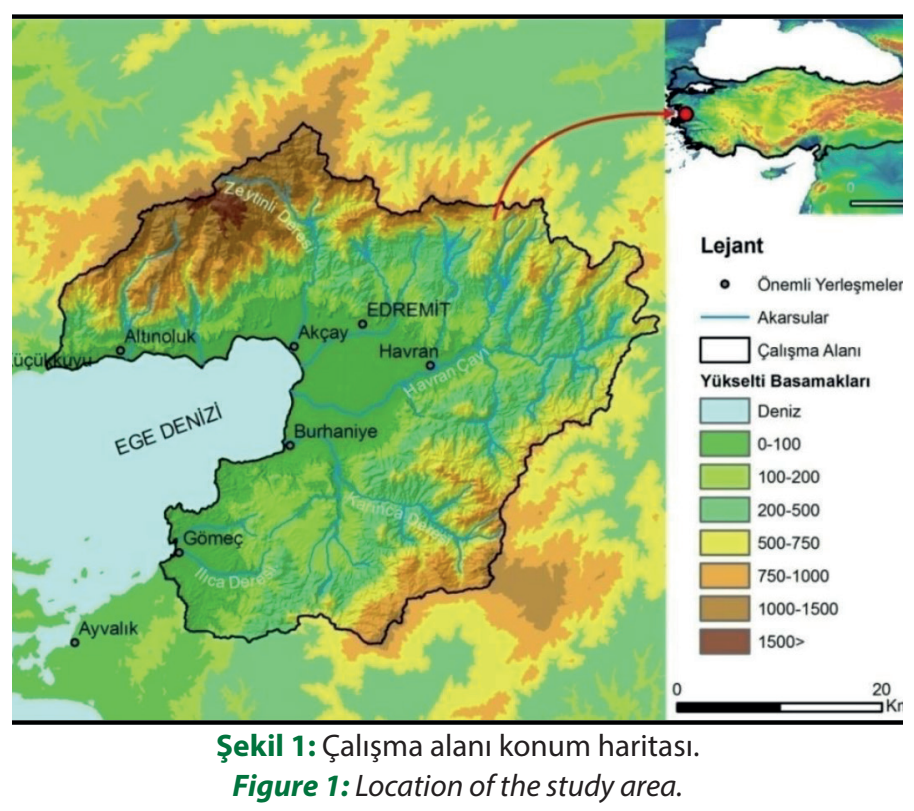

\subsection{Yöntem}

Tarım faaliyetlerine uygun alanların belirlendiği çalışmalarda genellikle toprak ve iklim verilerinden yararlanıldığı görülmektedir (Akbulak, 2010; Dağlı ve Çağlıyan, 2016; Deliba, Bağdatlı ve Danışman, 2015; Dengiz ve Özyazıc1, 2018; Torunlar ve Nazlıcan, 2018). Doğal ortamı temsil eden kriterler sadece tarıma uygun alanların belirlenmesi kapsamında değil tüm arazi kullanımı türlerine yönelik uygunluk çalışmaları için ihtiyaç duyulan parametrelerden biridir (Demir vd., 2011). Arazi Kullanım Planlaması konulu çalışmalarda çok çeşitli kriterler ele alınabildiği gibi arazi uygunluk düzeylerinin belirlenmesi konusunda kullanılan yöntemlerin de sayıları oldukça fazladır 
(Akıncı vd., 2013). Bu çalışmada arazi uygunluk düzeylerinin belirlenmesi için AHS'den yararlanılmıştır.

AHS, ilk olarak 1968 yilında Myers ve Alpert ikilisi tarafından ortaya atılmıs ve 1977 yılında Saaty tarafından bir model olarak geliştirilerek karar verme problemlerinin çözümünde kullanılabilir hale getirilmiştir (Uzun ve Kazan, 2016). AHS, karar hiyerarşisinin tanımlanmasında kararı etkileyen faktörler açısından karar noktalarının yüzde dağılımlarını veren ve kriterleri önem derecesine göre 1-9 arasında bir puanlama ile tercih edilme önceliğinin tanımlanmasına dayanmaktadır (Tablo 1). Coğrafi verilerin birbirleri ile karşılaştırılması için ÇKKV süreçlerinin temelini oluşturan mekânsal etkileşim veri matrisleri kullanılmaktadır (Mazlczewski, 1999). Çalışmanın yöntem kısmında uzmanlar tarafından verilen puanların geometrik ortalamaları alınmış ve verilere ait tutarlılık katsayıları ikili karşılaştırma matrisleri yardımı ile hesaplanarak puanlama sürecinin güvenilirliği test edilmiştir.

Tablo 1: AHS tekniğinde tercihler için kullanılan ikili karşılaştırmalar ölçeği.

Table 1: Binary comparisons scale for preferences in AHS technique.

\begin{tabular}{|c|c|c|}
\hline Sözel İfade & Açıklama & Değer \\
\hline $\begin{array}{l}\text { Eşit Tercih } \\
\text { Edilme }\end{array}$ & $\begin{array}{l}\text { İki faaliyet amaca eşit düzeyde katkıya } \\
\text { sahiptir. }\end{array}$ & 1 \\
\hline $\begin{array}{l}\text { Kısmen Tercih } \\
\text { Edilme }\end{array}$ & $\begin{array}{l}\text { Tecrübe ve yargı bir faaliyeti diğerine göre } \\
\text { kısmen tercih ettiriyor }\end{array}$ & 3 \\
\hline $\begin{array}{l}\text { Oldukça Tercih } \\
\text { Edilme }\end{array}$ & $\begin{array}{l}\text { Tecrübe ve yargı bir faaliyeti diğerine göre } \\
\text { oldukça tercih edilmekedir. }\end{array}$ & 5 \\
\hline $\begin{array}{l}\text { Kuvvetle Tercih } \\
\text { Edilme }\end{array}$ & $\begin{array}{l}\text { Bir faaliyet değerine göre kuvvetle tercih } \\
\text { ediliyor ve baskınlığı uygulamada rahatılıkla } \\
\text { görünmektedir. }\end{array}$ & 7 \\
\hline $\begin{array}{l}\text { Kesinlikle Tercih } \\
\text { Edilme }\end{array}$ & $\begin{array}{l}\text { Bir faaliyetin değerine göre tercih edilmesi- } \\
\text { ne ilişkin kanıtlar çok büyük bir güvenirliğe } \\
\text { sahiptir. }\end{array}$ & 9 \\
\hline Orta Değerler & $\begin{array}{l}\text { Uzlaşma gerektiğinde kullanılmak üzere iki } \\
\text { ardışık yargı arasına düşen değerleri temsil } \\
\text { etmektedir. }\end{array}$ & $2,4,6,8$ \\
\hline $\begin{array}{l}\text { Ters (Karşıt) } \\
\text { Değerler }\end{array}$ & $\begin{array}{l}\text { Bir eleman başka bir elemanla karşılaştırı- } \\
\text { dığında yukarıdaki değerlerden birisi atanır. } \\
\text { Bunlardan ikinci eleman birinci eleman ile } \\
\text { karşılaştırıldığında ters değere sahip olur. }\end{array}$ & $1 / ?$ \\
\hline
\end{tabular}

Tarım alanlarının uygunluk ölçütlerinin belirlenmesinde arazi kullanımı kabiliyet sınıfı, su varlığına yakınlık, erozyon, bitki varlığı, eğim, yağış, toprak grupları, toprak derinliği gibi çeşitli parametreler kullanılmaktadır (Akıncı vd., 2013, Demir vd., 2011; Erdoğan vd., 2013). Kriterlerin seçiminde literatürde yer alan Arazi Kullanımı Kabiliyet Sinıflandırılmasının tercih edilmemesinin nedeni bu çalışmanın ben zer bir anlam taşıyan bu sinıflandırmaya alternatif olarak geliştirilmesidir. Bazı araştırmalarda ele alınan erozyon, bitki varlığı, yağış ve toprak verimliliği gibi parametrelerin ÇDAİ kapsamında değerlendirilmesinden dolayı tarıma uygun alanların belirlenmesinde tekrardan model kapsamında alınmamıștır. Bunun nedeni sözü edilen parametrelerin önceki çalışmalarda sonuca olan etkilerinin yani ağırlık katsayılarının düşük olmasıdır (Akıncı, Özalp ve Özalp, 2017; Dengiz ve Usul, 2018). Ancak toprak taşlılığı, toprak derinliği ve eğim gibi parametrelerin tarımsal uygunluk düzeylerinin belirlenmesinde oldukça önem taşımaktadır (Akıncı vd., 2013; Akıncı vd., 2017; Erdoğan vd., 2013). Bu çalışmada tarıma uygun alanların belirlenmesinde arazinin beşeri ve fiziki unsurları dikkate alınarak toprak derinliği, toprak taşlılığı, eğim, arazi kullanımı, su kaynaklarına mesafe ve ÇDAİ parametrelerinin kullanılmasına karar verilmiştir (Tablo 2).

Tablo 2: Tarıma uygun alanların belirlenmesinde kullanılan kriterler, alt kriterler ve uygunluk değerleri.

Table 2: Criteria, sub-criteria and suitability values used in determining the areas suitable for agriculture.

\begin{tabular}{|c|c|c|c|}
\hline Kriter & Alt Kriter & $\begin{array}{c}\text { Uygunluk } \\
\text { Derecesi }\end{array}$ & $\begin{array}{c}\text { Uygunluk } \\
\text { Ağırlığı }\end{array}$ \\
\hline \multirow{5}{*}{ Ç.D.A.í. } & Düşük kalite & Çok uygun & 5 \\
\hline & Orta kalite & Orta uygun & 4 \\
\hline & Yüksek kalite & Düşük uygun & 3 \\
\hline & Çok düşük kalite & Sınırda uygun & 2 \\
\hline & $\begin{array}{l}\text { Çok yüksek } \\
\text { kalite }\end{array}$ & Hiç uygun değil & 1 \\
\hline \multirow{5}{*}{$\begin{array}{l}\text { Su Kaynakla- } \\
\text { rına } \\
\text { Mesafe }\end{array}$} & $<500 m$ & Çok uygun & 5 \\
\hline & $500-1000 \mathrm{~m}$ & Orta uygun & 4 \\
\hline & $1000-2000 \mathrm{~m}$ & Düşük uygun & 3 \\
\hline & $2000-3000 \mathrm{~m}$ & Sınırda uygun & 2 \\
\hline & $>3000 \mathrm{~m}$ & Hiç uygun değil & 1 \\
\hline \multirow{5}{*}{$\begin{array}{l}\text { Toprak } \\
\text { Derinliği }\end{array}$} & $>90 \mathrm{~cm}$ & Çok uygun & 5 \\
\hline & $50-90$ & Orta uygun & 4 \\
\hline & $20-50$ & Düşük uygun & 3 \\
\hline & $5-20$ & Sınırda uygun & 2 \\
\hline & Kayalık-Litozolik & Hiç uygun değil & 1 \\
\hline \multirow{6}{*}{$\begin{array}{l}\text { Arazi } \\
\text { Kullanımı }\end{array}$} & Tarım & Çok uygun & 5 \\
\hline & Açık alan & Düşük uygun & 3 \\
\hline & Otlak & Sınırda uygun & 2 \\
\hline & Orman & Hiç uygun değil & 1 \\
\hline & Yerleşme & Hiç uygun değil & 1 \\
\hline & $0-6^{0}$ & Çok uygun & 5 \\
\hline \multirow{5}{*}{ Eğim } & $6-12^{0}$ & Orta uygun & 4 \\
\hline & $12-20^{\circ}$ & Düşük uygun & 3 \\
\hline & $20-30^{\circ}$ & Sınırda uygun & 2 \\
\hline & $>30^{\circ}$ & Hiç uygun değil & 1 \\
\hline & $<\% 10$ & Çok uygun & 5 \\
\hline \multirow{4}{*}{ Taşlılık } & $\% 10-\% 30$ & Orta uygun & 4 \\
\hline & $\% 30-\% 60$ & Düşük uygun & 3 \\
\hline & $\% 60-\% 90$ & Sınırda uygun & 2 \\
\hline & $>\% 90$ & Hiç uygun değil & 1 \\
\hline
\end{tabular}


$\mathrm{Bu}$ çalışmada tarıma uygun alanların belirlenmesinde kullanılan ÇDAI; toprak taşlılığı, toprak tekstürü, toprak derinliği, eğim, drenaj, toprak reaksiyon ve ana materyal hesaplanmasından oluşan Toprak Kalite İndeksi (TKİ); yangın riski, kuraklığa dayanım, Normalleştirilmiş Fark Bitki İndeksi, bitki kapalılık oranı, erozyon koruma düzeyi gibi parametrelerin ortalamasının alındığı Vejetasyon Kalite İndeksi (VKİ), yağış, kuraklık indeksi, potansiyel evapotranspirasyon, ve bak1 değerlerinden elde edilen İklim Kalite İndeksi (İKİ) ve arazi kullanımı ile koruma statülerinin uygunluk düzeylerine göre ağırlıklandırılarak değerlendirildiği Arazi Yönetim Kalite İndeksini (AYKİ) kapsayan çoklu bileşenlerden oluşmaktadır (Şekil 2). TKİ'nde yer alan verilerden biri olan eğim verisi
Harita Yüksek Komutanlığından alından 1/25000 ölçekli topografya haritalarından, toprak ana materyali Maden Teknik Arama Genel Müdürlüğü (MTA) tarafindan hazırlanan yine $1 / 25000$ ölçekli jeoloji haritalarından geriye kalan veriler ise araziden elde edilen örneklerin analizi ile elde edilmiştir. VKI kapsamında ele alınan veriler hazırlanmasında Orman Meşcere Haritaları, Landsat Uydu Görüntüleri ve arazi çalışmalarından yararlanılmıştır. İKİ'nin hesaplanmasında kullanılan parametreler Meteoroloji Genel Müdürlüğü (MGM) tarafindan tutulan uzun yıllık yağış ve sıcaklık verilerinden üretilmiştir. AYKİ hesaplanmasında kullanılan değerlerin belirlenmesinde Landsat 8 OLI görüntüleri yardımı ile oluşturulan arazi kullanımı ve arazi koruma statülerinden faydalanılmıştır.
Toprak Kalite İndeksi

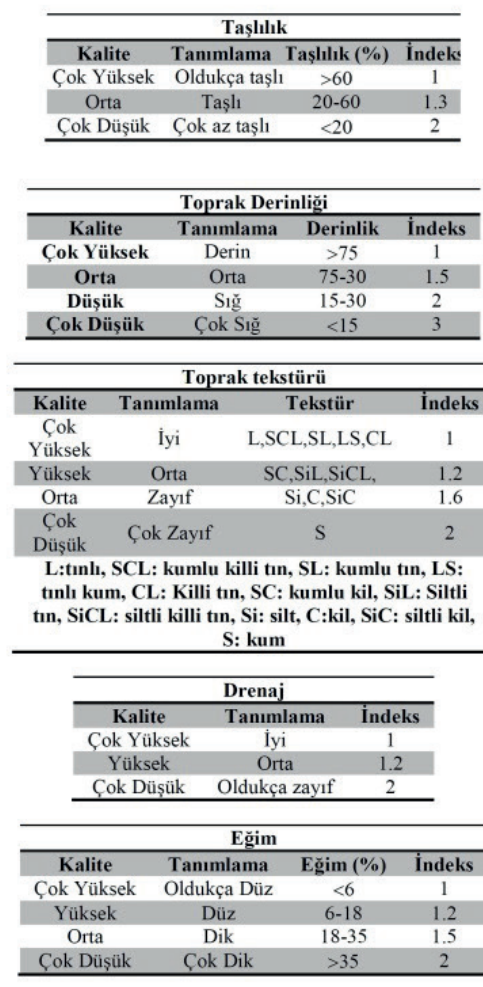

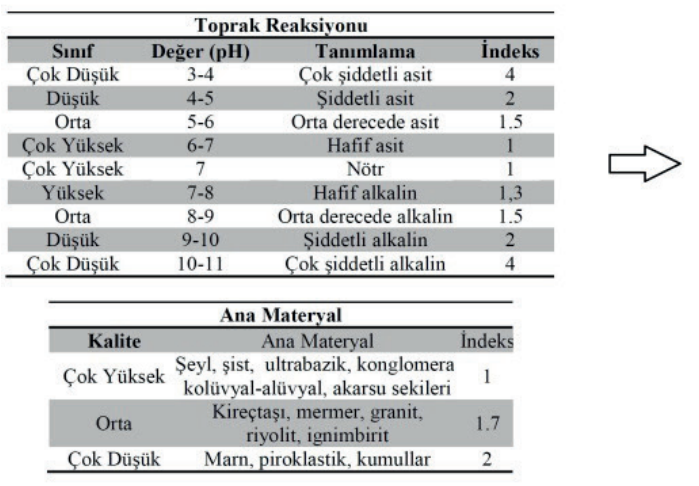

Vejetasyon Kalite İndeksi

\begin{tabular}{|c|c|c|}
\hline \multicolumn{3}{|c|}{ Yangin Riski } \\
\hline Kalite & Bitki örtüsü & İndeks \\
\hline Cok yüksek & Ciplak arazi, çok yıllık tarım bitkileri & 1 \\
\hline Yüksek & $\begin{array}{l}\text { Tek yıllık tarım bitkileri (tahıl, mera), } \\
\text { yaprak döken meșe ile her dem yeșil maki }\end{array}$ & 1.3 \\
\hline Orta & Akdeniz maki & 1.6 \\
\hline Cok düșük & Cam ormanları, tek yıllık bitkiler, yerleșme & 2 \\
\hline
\end{tabular}

\begin{tabular}{|c|c|c|}
\hline \multicolumn{3}{|c|}{ Erzoyondan Koruma } \\
\hline Kalite & Bitki örtüsü & Indeks \\
\hline Çok yüksek & Karışık Akdeniz Maki/Her dem yeşil orman & 1 \\
\hline Yüksek & $\begin{array}{l}\text { Akdeniz makisi, çam ormanı, kalıcı mera, } \\
\text { çok yıllık tarım bitkileri }\end{array}$ & 1.3 \\
\hline Orta & Yaprak döken ormanlar & 1.6 \\
\hline Düşük & Yaprak dőken çok yıllık tarım bitkileri (badem, erik) & 1.8 \\
\hline Çok düşük & Tek yillık tarım bitkileri, bağlar, yerlessme & 2 \\
\hline \multicolumn{3}{|c|}{ Kuraklık Dayanımı } \\
\hline Kalite & Bitki örtüsü & İndeks \\
\hline Çok yüksek & Karıșık Akdeniz Maki/Her dem yeșil orman & 1 \\
\hline Yüksek & İ̃ne yapraklı ormanlar, yaprak döken zeytinler & 1.2 \\
\hline Orta & Çok yıllık tarımsal ağaçlar (badem, erik) & 1.4 \\
\hline Düşük & Cok yılık mera bitkileri & 1.7 \\
\hline Çok Düşük & ek yıllık tarım bitkileri (tahıl) ve tek yıllık meralar, yerlesme & 2 \\
\hline
\end{tabular}

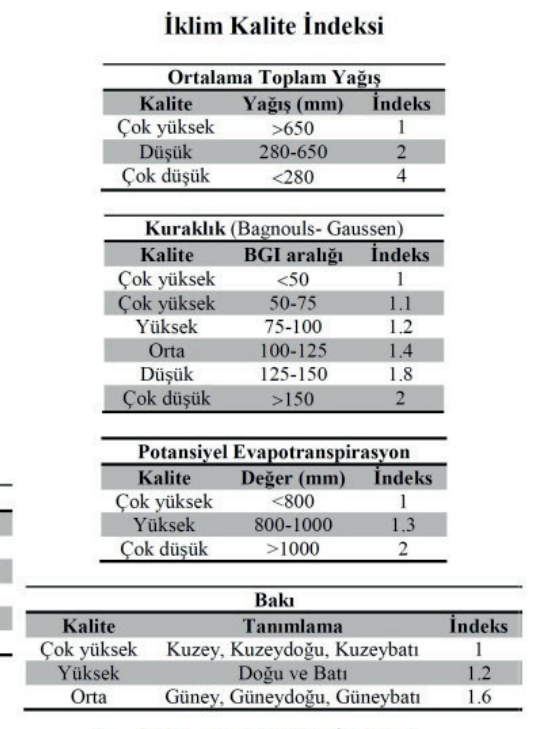

Arazi Yönetimi Kalite İndeksi

\begin{tabular}{ccc}
\hline \multicolumn{2}{c}{ Bitki Yüzey Kaplama (Kapalhlhk) } \\
\cline { 2 - 3 } Kalite & Örtme oram (\%) & Indeks \\
\hline Yüksek & $>40$ & 1 \\
Düșük & $10-40$ & 1.8 \\
\hline
\end{tabular}
$<10$

Çok düșük

\begin{tabular}{|c|c|c|}
\hline \multicolumn{3}{|c|}{ Normalleştirilmiş Fark Bitki Índeksi } \\
\hline Tanımlama & Indeks & Yansıma \\
\hline En yüksek & 1 & $200-130$ \\
\hline Yüksek & 1.3 & $130-120$ \\
\hline Düşük & 1.8 & $120-100$ \\
\hline
\end{tabular}

$\begin{array}{lll}\text { Duşuk } & 1.8 & 120-100 \\ \text { Cok Düsük } & 2 & <100\end{array}$<smiles></smiles>

\section{Çevresel Duyarlılık} Alan Índeksi (ÇDAI)

\begin{tabular}{|c|c|c|}
\hline \multicolumn{3}{|c|}{ Tarım Arazisi } \\
\hline$\overline{\text { Kalite }}$ & Tanımlama & Indeks \\
\hline Çok Yüksek & Düşük yoğunlukta arazi kullanımı & 1 \\
\hline Orta & Orta yoğunlukta arazi kullanımı & 1.5 \\
\hline Çok Düșük & Yüksek yoğunlukta arazi kullanımı & 2 \\
\hline \multicolumn{3}{|c|}{ Mera } \\
\hline Kalite & Tanımlama & İndeks \\
\hline Çok Yüksek & Halihazır stok oranı $<$ Sürdürülebilir stok oranı & 1 \\
\hline Orta & Halihazır stok oranı $=1.5 \mathrm{X}$ sürdürülebilir stok oranı & 1.5 \\
\hline Çok Düșük & Halihazır stok oranı $>1.5 \mathrm{X}$ sürdürülebilir stok oranı & 2 \\
\hline \multicolumn{3}{|c|}{ Doğal Alanlar } \\
\hline Kalite & Tanimlama & İndeks \\
\hline Çok Yüksek & Halihazır Üretim/ Sürdürülebilir verim $=0$ & 1 \\
\hline Orta & Halihazır Üretim/Sürdürülebilir verim $<1$ & 1.2 \\
\hline Çok Düșük & Halihazır Üretim/ Sürdürülebilir verim=1'den yüksek & 2 \\
\hline \multicolumn{3}{|c|}{ Maden Alanları } \\
\hline Kalite & Erozyon Kontrolü & İndeks \\
\hline Cok Yüksek & Uygun & 1 \\
\hline Orta & Orta & 1.5 \\
\hline Çok Düşük & Düșük & 2 \\
\hline \multicolumn{3}{|c|}{ Regreasyon Alanları } \\
\hline Kalite & Ziyaretçi Oramı (km/alan) & İndeks \\
\hline Çok Yüksek & $<1$ & 1 \\
\hline Orta & $1-2.5$ & 1.5 \\
\hline Çok Düşük & $>2.5$ & 2 \\
\hline
\end{tabular}

\begin{tabular}{ccc}
\hline & Politika & \\
\hline Kalite & Uygulama düzeyi & Indeks \\
Çok yüksek & Arazinin $\% 75^{\prime}$ ten fazlası koruma altında & 1 \\
Orta & Arazinin\% $\% 25 \% 75$ arası koruma altında & 1.5 \\
Çok düșük & Arazinin $\% 25$ 'ten azı koruma altında & 2 \\
\hline
\end{tabular}

Şekil 2: ÇDAI'yi oluşturan parametreler ve ağırlıklandırılmış alt kategoriler.

Figure 2: The parameters and weighted sub-categories that generate the ESAI. 
MEDALUS projesi kapsamında ortaya çıan ÇDAİ, doğal kaynakların devamlılığının sağlanması için önemli tehditler oluşturan çölleşme ve arazi bozulumu süreçlerinin önlenmesi kapsamında ortaya çıkmıştır (Kosmas vd., 1999). Bu olumsuzlukların etkilerinin azaltılması konusundaki temel uygulamalar net birincil üretimin belirlenmesi, doğal biyotik fonksiyonların açıklanması ve tarıma uygun alanların tespit edilmesi gibi uygulamalar şeklinde sıralanmaktadır (Lavado Contador vd., 2010). Doğal kaynaklar üzerinde kombine bir biçimde etkili olan ÇDAİ birçok çevresel kriterin bileşiminden üretilmekte ve arazinin ekolojik özelliklerini dikkate alan bir karar siteminin oluşmasına imkan sağlamaktadır (Alevkayalı, 2018).

Çevresel duyarlılık ve tarıma uygun alanların belirlenmesi arasındaki ilişki karmaşık bileşenlerden oluştuğundan uygunluk sınıflarının oluşturulmasında doğrusal ilişki kurulmamıştır (Tablo 2). Bu uygunluk düzeylerinin belirlenmesinde FAO’nun belirlediği şekilde 1-5 arasında değer verilen uygunluk puanlarından yararlanılmıştır (Yang vd., 2008). Buna göre 1 değerine sahip tarıma "hiç uygun olmayan" alanlar yani nadir doğal ekosistemlerdir. Taşlık-kayalık ve yerleşim alanlarına karşılık gelen tarım için "uygunsuz" sınıftaki arazilere 2 değeri verilmiştir. Çevresel duyarlılık açısından orta kalitedeki alanlar "düşük uygun" (uygunluk değeri 3) sinıfta değerlendirmeye alınmıştır. Tarım açısından orta kalitedeki alanlar tarıma "orta uygun" (uygunluk değeri 4) sinıfta ve düşük çevresel duyarlılıkla yüksek tarımsal verimliliğe sahip alanlar tarıma "çok uygun" (uygunluk değeri 5) sınıf kapsamında ele alınmıştır.

Her bir kriterin AHS ağırlık puanı ile alt- kriterlere ait uygunluk değerler arasında doğrusal kombinasyon oluşturularak sonuç haritası elde edilmiştir. Kriterlerin uygunluk sınıfları açısından ağırlıklandırımasının sonucunda elde edilen çıktılar anlamlılı̆̆ın arttırılması için literatürle uyumlu bir biçimde 4 sinıfta (çok uygun, uygun, az uygun, uygun değil) değerlendirilmiş̧ir (Akbulak, 2010; Çelikyay, Cengiz ve Görmüş, 2015; Erdoğan vd., 2013; Güzelmansur ve Yücel, 2013). Sonuç haritasının sınıflandırılmasında 2 ve altında ağırlık değerine sahip alanlar "uygun değil", 2-3 arasında değerle temsil edilenler "az uygun", 3,-4 ağırlık puanı ile temsil edilen alanlar "uygun" ve 4 üzerinde ağırlık değerinin hesaplandığ "çok uygun" olarak sinıflandırılmıştır. Parametrelerin sınıflandırılmasında toprak derinliği arttıkça uygunluk düzeyi artan, eğim arttıkça uygunluk düzeyi azalan, taşl11ık arttıkça uygunluk derecesi düşen ve su kaynaklarından uzaklaştıkça uygunluk düzeyinin azaldığı bir derecelendirme yaklaşımı kullanılmıştır. Arazi kullanımı konusunda yerleşme ve orman alanları uygun olmayan sinıfta yer alırken mevcut tarım alanları uygun sınıf kapsamında değerlendirmeye alınmıştır (Tablo 2).
Karar verme sürecinin oluşturulmasında amaca yönelik alternatif değerlendirmelerin oluşturulması sürecinde ağırlıklandırılan parametrelere ait değerlendirmeler 24 uzman görüşüne başvurularak elde edilmiştir. Bu uzmanlar Balıkesir Belediyesi, Edremit Belediyesi, Devlet Su İşleri 25. Bölge Müdürlüğü, Orman ve Su İşleri Balıkesir Şube Müdürlüğü, Balıkesir İl Gıda, Tarım ve Hayvancılık Müdürlüğünde çalışan ziraat mühendisi, çevre mühendisi, şehir plancisı, orman mühendisi, inşaat mühendisi, biyolog ve jeolog olarak görev yapan kişilerden oluşmaktadır. Bireysel karşılaştırmada ikili karşılaştırma düzeylerinin geometrik ortalamalarının kullanılması ile hiyerarşinin oluşturulmasında daha başarılı sonuçlar verdiği test edilmiştir (Ossadnik, Schinke ve Kapsar, 2015). Öncelikle her bir uzmanın verdiği yanıtların ikili karşılaştırma matrisi yapılmış daha sonra elde edilen sonuçların geçerliliğinin test edilmesi için değerler normalize edilerek öncelikler vektörü hesaplanmıştır (Tablo 3, 4). Daha sonra bu işlem her bir uzman için tekrarlanmıştır. Uzmanların verdikleri yanıtların geçerlilik ve güvenilirlik katsayılarının hesaplanmasında bir dizi işlemler gerçekleştirilmiştir (Formül 1,2,3,4):

$$
E_{i}=\frac{d_{i}}{w_{i}} \quad(i=1,2, \ldots, n)
$$

Tablo 3: 1 nolu uzmanın kriterlerin önem derecesini belirlemeye yönelik verdiği yanıtların ikili karşılaştırma matrisi.

Table 3: Binary comparison matrix of the expert 1 answers to determine the importance of the criteria.

\begin{tabular}{lcccccc}
\hline Kriterler & Td & Ak & Çd & Eğ & Taş & S.K. Mesafe \\
\hline Toprak Derinliği & 1 & 9 & $1 / 9$ & 1 & 5 & 1 \\
Arazi Kullanımı & $1 / 9$ & 1 & $1 / 9$ & $1 / 5$ & 1 & $1 / 6$ \\
Çevresel Duyarılılı & 9 & 9 & 1 & 9 & 9 & 6 \\
Eğim & 1 & 5 & $1 / 9$ & 1 & 6 & 1 \\
Taşlılık & $1 / 5$ & 1 & $1 / 9$ & $1 / 6$ & 1 & $1 / 5$ \\
Su Kaynaklarına Mesafe & 1 & 6 & $1 / 6$ & 1 & 5 & 1 \\
\hline
\end{tabular}

Tablo 4: 1 nolu uzmanın verdiği yanıtların Normalize edilmiş matris hesabı ve yanıtların Öncelikler Vektörü Ortalaması.

Table 4: Normalized matrix calculation of the expert 1 answers and the Priority Vector Mean of responses.

\begin{tabular}{|c|c|c|c|c|c|c|c|}
\hline Kriterler & Td & Ak & Çd & Eğ & Taş & $\begin{array}{c}\text { S.K. } \\
\text { Mesafe }\end{array}$ & $\begin{array}{c}\text { Öncelikler } \\
\text { Vektörü } \\
\text { (Ortalama) }\end{array}$ \\
\hline $\begin{array}{l}\text { Toprak } \\
\text { Derinliği }\end{array}$ & 0,081 & 0,290 & 0,069 & 0,081 & 0,185 & 0,107 & 0,136 \\
\hline $\begin{array}{l}\text { Arazi } \\
\text { Kullanımı }\end{array}$ & 0,009 & 0,032 & 0,069 & 0,016 & 0,037 & 0,018 & 0,030 \\
\hline $\begin{array}{l}\text { Çevresel } \\
\text { Duyarlılık }\end{array}$ & 0,731 & 0,290 & 0,621 & 0,728 & 0,333 & 0,641 & 0,557 \\
\hline Eğim & 0,081 & 0,161 & 0,069 & 0,081 & 0,222 & 0,107 & 0,120 \\
\hline Taşlılık & 0,016 & 0,032 & 0,069 & 0,013 & 0,037 & 0,021 & 0,032 \\
\hline \multicolumn{8}{|l|}{ Su } \\
\hline $\begin{array}{l}\text { Kaynaklarına } \\
\text { Mesafe }\end{array}$ & 0,081 & 0,194 & 0,103 & 0,081 & 0,185 & 0,107 & 0,125 \\
\hline
\end{tabular}




$$
\lambda=\frac{\sum_{i=1}^{n} E_{i}}{n}
$$

$1_{\text {maks }}$ hesaplanmasından sonra Tutarlılık Göstergesi (CI),

(3) formülünden yararlanarak hesaplanabilir.

$$
C I=\frac{\lambda_{\text {maks }}-n}{n-1}
$$

Son aşamada ise CI, Random Gösterge (RI) olarak adlandırılan ve standart olan RI düzeltme değerine bölünerek (4) formülü) $\mathrm{CR}$ elde edilir.

$$
C R=\frac{C I}{R I}
$$

Tüm Öncelikler Matrisinin hesaplanmas1:

$\left[\begin{array}{cccccc}1 & 9 & 1 / 9 & 1 & 5 & 1 \\ 1 / 9 & 1 & 1 / 9 & 1 / 5 & 1 & 1 / 6 \\ 9 & 9 & 1 & 9 & 9 & 6 \\ 1 & 05 & 1 / 9 & 1 & 6 & 1 \\ 1 / 5 & 1 & 1 / 9 & 1 / 6 & 1 & 1 / 5 \\ 1 & 6 & 1 / 6 & 1 & 5 & 1\end{array}\right] \quad \times \quad\left[\begin{array}{l}0,136 \\ 0,030 \\ 0,557 \\ 0,120 \\ 0,032 \\ 0,125\end{array}\right]=\left[\begin{array}{c}0,873 \\ 0,184 \\ 4,166 \\ 0,79 \\ 0,196 \\ 0,813\end{array}\right]$

$$
1_{\text {maks }} \text { değeri: }
$$

$$
\begin{gathered}
0,873 / 0,136=6,437 \\
0,03 / 0,184=6,079 \\
0,557 / 4,166=7,476 \\
0,12 / 0,79=6,571 \\
0,032 / 0,196=6,207 \\
0,125 / 0,813=6,494
\end{gathered}
$$

$1_{\text {maks }}$ değeri öncelikler vektörü elemanlarının ortalaması ile hesaplanır:

$$
(6,437+6,079+7,476+6,571+6,207+6,464) / 6=6,054
$$

CI yani tutarlılık göstergesinin hesaplanması:

$$
C I=\frac{6,054-6}{6-1}=0,108
$$

Rastgele değer indeksi 6 değişken sayısına göre standart olarak 1,24 değerindedir. Böylece tutarlılık oranı 0,0004 olarak hesaplanır:

$$
C R=\frac{0,022}{1,24}=0,089
$$

Hesaplanan Tutarlılık Oranının $0,089<0,1$ olması sonucun uyum sınırları içerisinde olduğu anlamı taşımaktadır. Modelin hesaplanmasında kullanılan ağırlık değerleri uzmanların yaptıkları karşılaştırmaların Tutarlılık Oranları açısından uygun sınırlarında olduğu belirlenenlere ait yanıtların geometrik ortalaması alınarak hesaplanmıştır:

Tarıma Uygun Alan $=($ ÇDAİ x 0,24) $+($ Su Kaynaklarına Mesafe x 0,221) $+($ Toprak Derinliği x 0,148) $+($ Arazi Kullanımı x 0,145$)+($ Eğim x 0,138$)+($ Taşlılık x0,108)

\section{BULGULAR}

Edremit Körfezi ve çevresi olarak belirlenen çalışma alanında tarıma uygunluk düzeylerinin tespit edilmesi amaciyla tasarlanan arazi kullanımı planlaması 4 sınıfta ele alınmıştır. Bu sınıflar arasında tarım faaliyetleri için en verimli ve en makul alanlar "ç̧ok uygun", her yönü ile tarıma elverişli olmayan ancak verimli araziler "uygun"; tarımsal faaliyetlere kısmen elverişli araziler "az uygun" ve hiç bir şekilde tarıma uygun olmayan alanlar "hiç uygun değil" şeklinde adlandırılmıştır (Şekil 3). Bu sınıflar ile mevcut arazi kullanımı ve planlamalar arasında karşılaştırmalar yapılabilmesi için sonuç verileri üzerine çakıştırma yöntemi ile bazı katmanlar eklenmiştir. Bunlardan ilki Tarım ve Orman Bakanlığı tarafından hazırlanan mevcut arazi kullanımları diğeri ise 644 sayılı Çevre ve Şehircilik Bakanlığının 02.04.2018 yılına ait kanun hükmündeki kararnamesinde 1/100000'lik çevre düzeni planında konut geliştirme alanlarıdır (Şekil 3).

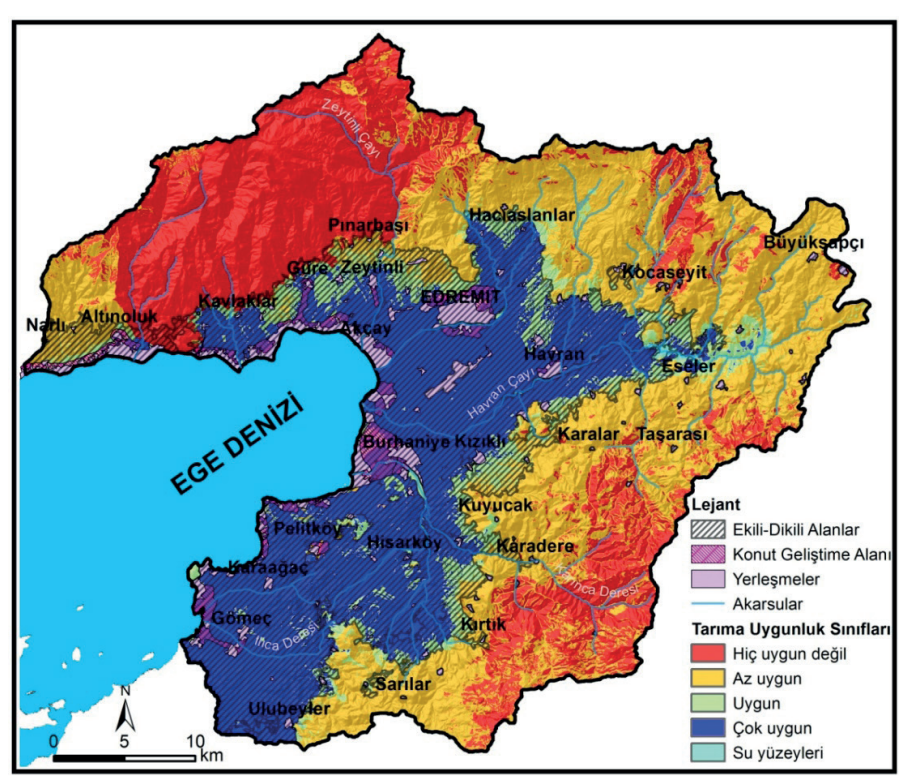

Şekil 3: Tarımsal arazi uygunluk sınıfları ve mevcut ekili-dikili alanlar. Figure 3: Land suitabilty for agriculture and current cultivated areas. 
Çalışma alanı sınırları içerisinde tarımsal uygunluk düzeylerine göre "çok uygun" sınıf sınırlarındaki araziler ekili-dikili tarımsal faaliyetlere en elverişli bölgeleri ifade etmektedir. Bu bölgeler çalışma alanında alüvyonlardan oluştuğu bilinen ova tabana karşılık gelmektedir (Şekil 3). Ayrıca tarıma "çok uygun” olarak belirlenen bölgenin tamamı mevcut ekili-dikili arazilerle örtüşmektedir. Tarıma "çok uygun" alanlar Edremit ovası dışında Kazdağları'nın güneyinde ve Madra Dağı'nın eteklerinde yer alan kıyı ovalarını da kapsamaktadır (Şekil 3). Gömeç kıyı ovası ile Edremit Ovası'nda gerçekleştirilen yaş sebze üretimi de bu bölgelerde gerçekleştirildiği arazi çalışmalarında dikkat çekmiştir. Ayrıca çalışma alanında imara açılması planlanan konut geliştirme alanlarının tarım arazilerinin bulunduğu bölgelere karşılık gelmesi tarım arazilerinin yapılaşma riski ile karşı karşıya olduğu yönündeki endişelerin yersiz olmadığını göstermektedir (Şekil 3). Buna göre mevcut planlar doğrultusunda yerleşmelerin çevresine doğru genişlemeleri tarıma "çok uygun" olarak belirlenen sınıfın daralması anlamı taşımaktadır.

Tarıma "uygun" olarak belirlenen sınıf, dar bir saha ile temsil edilmektedir (Şekil 3). Burada elde edilen bulgulardan biri tarıma "uygun" ve "çok uygun" alanlar ile mevcut ekili-dikili alanlarının tam olarak örtüşmemesidir. Arazi kullanımı uygunluk düzeyleri dikkate alındığında tarıma "uygun" olarak belirlenen sınıfın Eseler ve Hacıaslanlar'ın doğusunda mevcut ekili dikili arazilerden daha geniş alanı temsil ettiği görülmektedir (Şekil 3). Bu alanların arazide yapılan gözlemlerde tarım faaliyetlerinin yapılmadığı bozuk korulardan oluşmaktadır (Şekil 4, Şekil 5). Buradaki bozuk korular arasında düzensiz zeytin ağaçlarının olduğu da dikkat çekmektedir. Arazide yapılan gözlemler ile uzman görüşlerine dayandırılarak oluşturulan tarıma uygun alanların mevcut tarım arazileriyle yüksek oranda (\%98) örtüştüğü tespit edilmiştir.

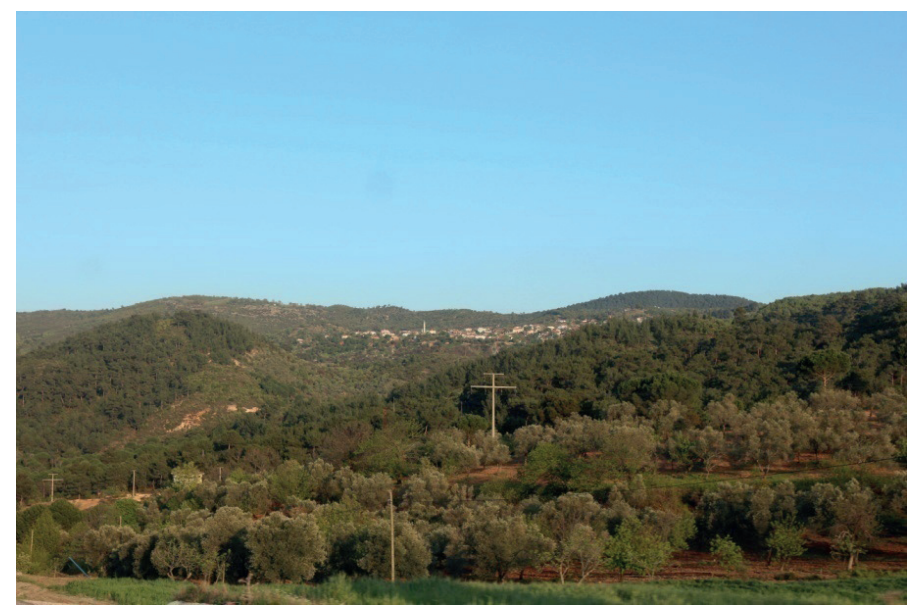

Şekil 4: Eseler'de bulunan bozuk korulardan bir görünüm. Figure 4: A view from the degraded forest cover seen in Eseler.
Çalışma alanının önemli bir kısmında tarıma "uygun" alanların orman sınırına ulaştığı ve tarımsal faaliyetlerin genişlemesi durumunda doğal ortama zarar verme potansiyeline sahip olduğu anlaşılmaktadır. Çalışma alanında tarım arazilerinin Kazdağı Milli Park'1 yönünde gelişmesinin yasalarla sınırlandırıldığı hesaba katılırsa buradaki arazi örtüsü değişiminin daha çok çalışma alanının doğu ve güney kısımlarında gerçekleşme potansiyeline sahip olduğu sonucuna varılmaktadır. Tarıma uygunluk düzeyleri açısından ortaya çıkan bulgular doğal alanlar yani ormanların tarımsal faaliyetler için uygun olmadığını göstermektedir. Ancak çalışma alanındaki yüksek kesimlerinde zeytinliklerin orman arazileri ile karışı bir biçimde görülmesi ormanların tarımsal faaliyetlerin baskısı altında olduğunu göstermektedir (Şekil 4, Şekil 5).

Tarıma uygun araziler açısından elde edilen diğer bir bulgu tarım açısından son derece elverişli olan bölgelerin turizm faaliyetleri ve yapılaşmanın olduğu alanlara karşılık gelmesidir (Şekil 3). Örneğin, bölgenin önemli turizm destinasyonlarından biri olan Burhaniye'ye bağlı Ören yerleşmesinin çevresinde çoğunluğu zeytinliklerden oluşan tarım arazileri yer almaktadır (Şekil 6). Buradaki olumsuz etkiler sadece yapılaşma ile sınırlı olmadığı kontrolsüz turizm faaliyetleri ve günlük rekreasyonel faaliyetlerden kaynaklanan çevre tahribatının da olduğu bilinmektedir (Kocadağl, 2009).

Arazi kullanımı uygunluk sınıflarından tarıma "az uygun ve "hiç uygun değil" sınıflarının daha çok yükseltinin arttığı alanlar ile temsil edildiği görülmektedir (Şekil 3). Tarım açısından yeterli koşulları barındırmayan ve "az uygun" sınıfında değerlendirilen arazilerin bazı bölgelerde mevcut ekili arazilerin sınırları içerisinde yer alması dikkat çekmektedir. $\mathrm{Bu}$ alanlar Narlı-Altınoluk arasında, Pınarbaşı-Edremit arasında ve Karadere çevresine karşl1ık gelmektedir (Şekil 3). Bu bölgelerde genel olarak zeytin

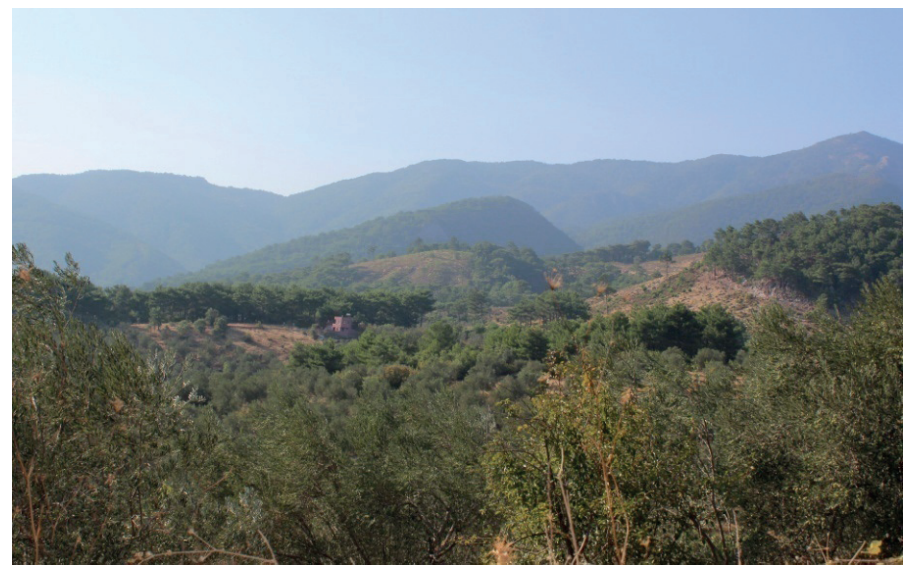

Şekil 5: Hacıaslanlar yakınlarında bozuk korulardan bir görüntü. Figure 5: A view from the degraded forests around the Haciaslanlar. 


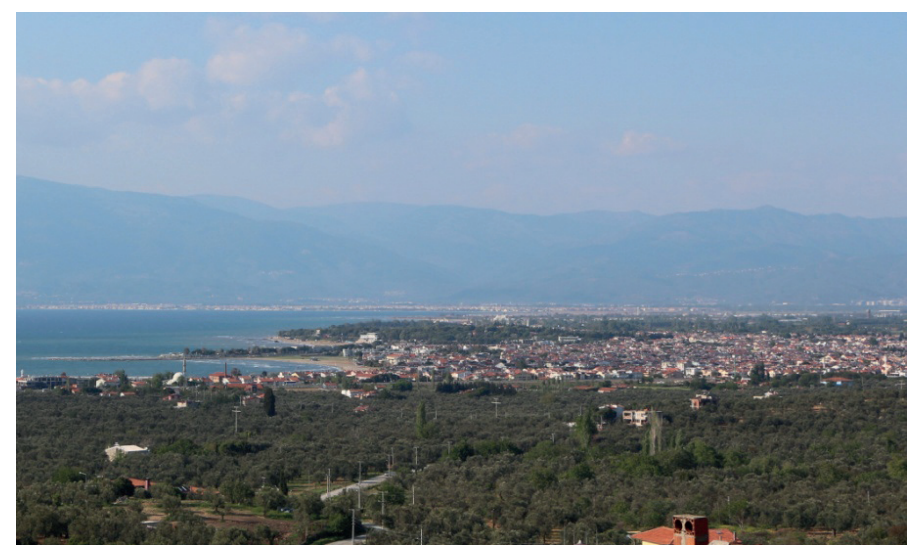

Şekil 6: Zeytinliklerin arasında yer alan Burhaniye Ören'den bir görüntü.

Figure 6: A view from Burhaniye Ören that located among the olive groves.

tarımı yapıldığı ve söz konusu alanlarda yüksek verim alınamadığ1 arazi çalışmalarında gözlenmiştir. Tarıma "hiç uygun değil" sınıfı ile temsil edilen araziler, çalışma alanında koruma alanına ve toprak gelişiminin oldukça az olduğu açık arazilere (kayalık) karşılık gelmektedir. Toprak gelişiminin az ya da hiç olmadığı alanlar genel olarak bitki örtüşünün seyrek olduğu dağların yüksek kesimleri, vadiler ve dik yamaçlarla temsil edilmektedir (Şekil 3). Ayrıca yerleşmelerin ve diğer beşeri yapıların bulunduğu bölgeler beklendiği üzere tarıma hiç uygun olmayan sınıfta yer almaktadır. Kazdağı Milli Parkı'nın bulunduğu bölgenin tarımsal faaliyetler açısından uygun koşulları sağlamamasının temel nedeni koruma alanı statüsünde olmasıdır. Dahası bu çalışmada birçok doğal ekosisteme ev sahipliği yapan Kazdağları ve Madra Dağı'nın büyük bir kısmının tarıma hiç uygun olmayan sınıfta yer almasının nedeni çevresel duyarlılığın arazi kullanım planlamasının oluşturulmasına yönelik karar verme sürecinde temel bileşenlerden biri olarak değerlendirilmesidir.

\section{SONUÇ VE TARTIŞMA}

Edremit Körfezi'nde son yıllardaki arazi kullanımı/arazi örtüsündeki değişimlerin tarım alanlarının yerleşmeye dönüşmesi ve yeni tarım alanları açılımı için doğal alanların tahrip edilmesi şeklinde gerçekleşmektedir (Tağıl, 2014; Uzun ve Somuncu, 2015). Bitkisel üretim açısından uygun koşulları barındırdığı belirlenen bölgede Edremit, Burhaniye, Akçay ve Havran'ın gibi önemli yerleşmelerin bulunması arazi özellikleri dikkate alınmadan yerleşme planlarının tasarlandığını göstermektedir. $\mathrm{Bu}$ yerleşmelerin çevresine doğru genişlemeleri durumunda tarımsal alanların tahrip edilmesi ve tarımda sürdürülebilirliğin zarar görmesine neden olacağı anlaşılmaktadır. Bu çalışmada elde edilen sonuçlar Tağıl (2014) tarafindan da ifade edilen
Edremit Körfezi'nde ekili-dikili alanların yapılaşma baskısına maruz kaldığı görüşünü desteklemektedir. Çalışma alanı içerisinde tarım alanları üzerindeki olumsuz etkilerin yaz aylarında turizm ile daha güçlendiği bilinmektedir. Yaz aylarında turizm faaliyetlerinin artmasının temel sebebi 1990'lı yılınlardan bu yana turizm teşvikleri ile ikincil konut sayısının artmasıdır. (Duran, Günek ve Sandal, 2012). Bu durum Edremit Körfezi'nde son 30 yılda ikincil konut yapımı için yaklaşı olarak 1,5 milyon zeytin ağacının kesilmesi ile kendini göstermiştir (Kocadağlı, 2009).

Türkiye'de çeşitli bölgelerde yapılan arazi uygunluk çalışmalarda tarım alanları, orman arazileri ve yerleşmeler arasında arazi uygunluk değerleri ile mevcut arazi kullanımları arasında bazı aykırı durumlar olduğu belirlenmiştir.(Çavuş ve Koç, 2015; Özel Cengiz, 2011). Bu aykırı durumların temelinde hukuki bazı eksikliklerin olduğu dikkat çekmektedir (Çavuş ve Koç, 2015). Bu çalışmada ele alınan ÇDAİ, çevre ve yönetim tabanlı kriterlere dayandırılmasından dolayı hukuki sınırlamalar açısından değerlendirmeler yapılmasına imkân vermektedir.

$\mathrm{Bu}$ çalışmada tarıma uygun alanların belirlenmesi amacıyla tasarlanan arazi kullanım planlamasının mevcut durumun açıklanmasında başarılı sonuçlar üretildiği görülmektedir. Ayrıca çevresel duyarlılık düzeylerinin model girdilerinden biri olmasının önemli doğal ortam-tarım dengesinin kurulmasında kilit rol oynadığı belirlenmiştir. Özellikle mekânsal teknolojiler yardımı ile bölgeyi tanıyan uzmanların görüşlerinden yararlanılarak oluşturulan alternatif kriter dizilimleri ve arazi potansiyelinin dikkate alınması Arazi Kullanım Planlamalarının verimli arazi kullanımı başarısını arttırdığı ortaya konulmuşstur.

\section{SON NOTLAR}

Bu çalışma Prof. Dr. Şermin TAĞIL danışmanlığında Çağan ALEVKAYALI tarafından hazırlanan "Edremit Körfezi'nde Arazi Degradasyonu ve Sürdürülebilir Arazi Planlaması" adlı doktora tezinden üretilmiştir.

Hakem Değerlendirmesi: Dış bağımsız.

Çıkar Çatışması: Yazarlar çıkar çatışması bildirmemiştir.

Finansal Destek: Yazarlar bu çalışma için finansal destek almadığını beyan etmiştir.

Peer-review: Externally peer-reviewed.

Conflict of Interest: The authors have no conflict of interest to declare.

Grand Support: The authors declared that this study has received no financial support. 


\section{KAYNAKÇA/REFERENCES}

Akbulak, C. (2010). Analitik hiyerarşi süreci ve coğrafi bilgi sistemleri ile Yukarı Kara Menderes Havzası'nın arazi kullanımı uygunluk analizi. Uluslararasi Insan Bilimleri Dergisi, 7(2), 557-576.

Akıncı, H., Özalp, A. Y., \& Turgut, B. (2013). Agricultural land use suitability analysis using GIS and AHP technique. Computers and Electronics in Agriculture, 97, 71-82.

Akınc1, H., Özalp, A. Y., \& Özalp, M. (2017). Investigating Impacts of Large Dams on Agricultural Lands and Determining Alternative Arable Areas Using GIS and AHP in Artvin, Turkey. SUJEST. 5(1), 83-95.

Akpoti, K., Kabo-bah, A. T., \& Zwart, S. J. (2019). Agricultural land suitability analysis: State-of-the-art and outlooks for integration of climate change analysis. Agricaltural systems, 173, 172-208.

Alevkayal1, Ç. (2018). Edremit Körfezi’nde Arazi Degradasyonu ve Sürdürülebilir Arazi Planlaması (Doktora Tezi). Balıkesir Üniversitesi Sosyal Bilimler Enstitüsü. Balıkesir.

Berke, P. R., Godslchalk, D. R., Kaiser, E. J., \& Rodriguez, D. A. (2006). Urban Land Use Planning. Chicago: University of Illinois Press.

Bouhata, R., \& Kalla, M. (2014). Mapping of environmental vulnerability of desertification by adaptation of the MEDALUS method in the endoreic area of Gadaine (Eastern Algeria). Geographia Technica. 9, 1-8.

Çavuş, C. Z. ve Koç, T. (2015). Çanakkale Boğazı Doğusunda Arazi Kullanım Uygunluğunun Yerleşme Açısından Analizi. Coğrafi Bilimler Dergisi, 13(1), 41-60.

Çelikyay, S., Cengiz, S. ve Görmüş, S. (2015). Coğrafi Bilgi Sistemleri İle Baartın İli’nin Arazi Kullanımı Uygunluk Analizi. Bartın Orman Fakültesi Dergisi, 17(25-26), 73-81.

Dağl1, D. ve Çağliyan, A. (2016). Analitik hiyerarşi süreci ile optimal arazi kullanımının belirlenmesi: Melendiz Çayı havzası örneği. Türk Coğrafya Dergisi, 66, 83-92.

Delibaş, L., Bağdatlı, C. ve Danışman, A. (2015). Topoğrafya ve Bazı Toprak Özelliklerinin Coğrafi Bilgi Sistemleri (CBS) Ortamında Analiz Edilerek Ceviz Yetiştiriciliğine Uygun Alanların Belirlenmesi: Tekirdağ İli Merkez Köyleri Örneği. Gümüşhane Üniversitesi Fen Bilimleri Enstitüsü Dergisi, 5(1), 50-59.

Demir, M., Yıldız, N., Bulut, Y., Yılmaz, S. ve Özer, S. (2011). Alan Kullanım Planlamasında Potansiyel Tarım Alanlarının Ölçütlerinin Coğrafi Bilgi Sistemleri (CBS) Yöntemi İle Belirlenmesi (İspir Örneği). Iğdır Üniversitesi Fen Bilimleri Enstitüsü Dergisi, 1(3), $77-86$.

Dengiz, O. ve Özyazıcı, M. A. (2018). Çeltik tarımına uygun alanların belirlenmesinde çok kriterli arazi değerlendirme. Toprak Bilimi ve Bitki Besleme Dergisi, 6(1), 19-28.

Dengiz, O., \& Usul, M. (2018). Multi-criteria approach with linear combination technique and anaytical hiyerarchy process in land evaluation studies. Eurasian Journal of Soil Science, 7(1), 20-29.

Doğanay, H. (2011). Türkiye Ekonomik Coğrafyası. Ankara: Pegem Akademi yayınları.
Duran, C., Gunek, H. \& Sandal, E.K. (2012). Effects of Urbanization on Agricultural Lands and River Basins: Case Study of Mersin (South of Turkey). Journal of Environmental Biology, 33, 363-371.

Erdoğan, Ö., Çabuk, A., Memlük, Y. ve Perçin, H. (2013). Ekolojik Alan Kullanım Kararlarına Uygun Alanların AHP Yöntemi Kullanılarak Kütahya Kenti Örneğinde İncelenmesi. Harita Teknolojileri Elektronik Dergisi, 5(1), 26-36.

Garipağaoğlu, N. (2012). Havza Planlamalarında Coğrafyanın Rolü ve Türkiye'de Havza Planlamacılığı. Atatürk Üniversitesi Sosyal Bilimler Enstitüsü Dergisi, 16(2), 303-336.

Güzelmansur, A. ve Yücel, M. (2013). Amik Ovası ve Çevresinin Sürdürülebilir Alan Kulanım Planlaması. Ç.Ü. Fen ve Mühendislik Dergisi, 29(1), 70-80.

Kocadağlı, A. Y. (2009). Türkiye'de Zeytincilik Faaliyetlerinde Edremit Körfezi Kıyılarının Önemi. Istanbul Üniversitesi Edebiyat Fakültesi Coğrafya Dergisi, 19, 28-58.

Kosmas, C., Ferrara, A., Briasouli, H., \& Imeson A. (1999). Methodology for mapping Environmentally Sensitive Areas (ESAs) to Desertification In: Kosmas C., Kirkby M., Geeson N. (Ed). The Medalus project: Mediterranean desertification and land use. Manual on key indicators of desertification and mapping environmentally sensitive areas to desertification.

Kurucu, Y. ve Güverhan, S. S. (2013). Mekânsal Planlarda Doğal Yap1 Envanteri: İzmir İli Örneği. TMMB 2. İzmir Kent Sempozyumu. 57-67, Ankara.

Lavado Contador, J. F., Schnabel, S., Gómez Gutiérrez A., \& Pulido Fernández M. (2010). Mapping Sensitivity to Land Degradation in Examadura SW. Spain. Boletín de la Asociación de Geógrafos Españoles N. ${ }^{\circ} 53$ - 2010, págs. 387-390.

Malczewski, J. (1999). GIS and Multi Criteria Decision Analysis. Wiley press: Canada.

Malczewski, J. (2004). GIS based Land Use Suitability Analysis: A Critical Overview. Progress in Planning, 62, 3-65.

Malczewski, J. (2006). Integrating Multi---criteria Analysis and Geographic Information Systems: The Ordered Weighted Averaging (OWA) Approach. International Journal of Environmental Technology and Management, 6(2), 7-19.

Ossadnik, W., Schinke S. \& Kaspar R. H. (2016). Group aggregation techniques for analytic hierarchy process and analytic network process: a comparative analysis. Group Decis Negot, 25(2), 421457.

Özdağoğlu, A. ve Özdağoğlu, G. (2007). Comparison of AHP And Fuzzy AHP For The Multicriteria Decision Making Processes with Linguistic Evaluations. İstanbul Ticaret Üniversitesi Fen Bilimleri Dergisi, 6(11), 65-85.

Özel Cengiz, A. E. (2011). Ekolojik Açıdan Kentsel Alan Kullanımları: Çanakkale Kent Merkezi Örneği (Doktora Tezi). Çanakkale Onsekiz Mart Üniversitesi Fen Bilimleri Enstitüsü, Çanakkale.

Saaty, T. L. (1990). How to Make a Decision: The Analytic Hierarchy Process. European Journal of Operations Research, 48, 9-26. 
Tağıl, Ş. (2014). Edremit Körfezi’nin Kuzey Sahil Bölgesinde peyzaj paterni ve arazi örtüsünün zamansal ve mekânsal değişimi. Balıkesir Üniversitesi Sosyal Bilimler Enstitüsü Dergisi, 17(31), 1-16.

Toprak ve Arazi Sınıflandırması Standartları Teknik Talimat1 (2008).

Tarım ve Köy İşleri Bakanlığı, (2008). Toprak ve Arazi Sınıflandırması Standartları Teknik Talimatı. Ankara: Tarım ve Köy İşleri Bakanlığı.

Toprak Koruma ve Arazi Kullanımı Kanunu (2005, 19 Temmuz). Resmi Gazete, (Say1: 25880).

Torunlar, H. ve Nazlıcan, A. (2018). Türkiye'de ana ürün olarak yetiştirilecek soyanın (glycine max L.merrill) çok kriterli karar verme yöntemiyle arazi uygunluk analizinin yapılması. Anadolu Tarım Bilimleri Dergisi, 33(3), 270-281.

Tümertekin, E. ve Özgüç, N. (2015). Ekonomik Coğrafya Küreselleşme ve Kalkınma. İstanbul: Kuram Yayıncılık.
Uzun, S. ve Kazan, H. (2016). Çok Kriterli Karar Verme Yöntemlerinden AHP TOPSİS ve PROMETHEE karşılaştırması: Gemi İnşada Ana Makine Seçimi Uygulaması. Journal of Transportation and Logistics. 1(1), 99-113.

Uzun, A. ve Somuncu, M. (2013). Madra Dağı ve Çevresinin Arazi Örtüsü/ Kullanımındaki Zamansal Değişimin Uzaktan Algılama Yöntemi ile Değerlendirilmesi. Balıkesir Üniversitesi Sosyal Bilimler Enstitüsü Dergisi, 16(30), 1-21.

Yang, F., Zeng, G. M., \& Du, C. Y. (2008). Spatial analyzing system for urban land-use management based on GIS and multi-criteria assessment modelling. Progress in Natural Science. 10, 1279-1284.

Y1lmaz, E. (2005). Bir Arazi Kullanım Planlamast Modeli: Cehennemdere Vadisi Örneği. Çevre ve Orman Bakanlığı Yayın No: 253, Mersin: Çeşitli Yayın. 
